\title{
HUBUNGAN ANTARA PENGETAHUAN DAN TINDAKAN DOKTER GIGI DALAM UPAYA PENCEGAHAN PENYAKIT MENULAR
}

\author{
Annisa Meirani Hidayat ${ }^{*}$, Kusuma Arbianti ${ }^{* *}$, Erdianto Setya Wardhana**
}

Keywords:

Infectious Diseases,

Dentist, Infection

Control Knowledge,

Precaution of

Infection Disease

\begin{abstract}
Background: Infectious disease is a disease caused by a particular toxin. Infectious diseases that acquired from the hospital environment called nosocomial infections. Hepatitis B, tuberculosis, and HIVIAIDS is a commonly infectious disease that often found in dental practice. The risk for dentist to infected the infectious diseases are very high, due to direct contact with saliva. The awareness of infection control at the dentist is very important to prevent disease transmission. This aim of this research is to determine the relationship between the level of knowledge of the dentist with the precautions against infection diseases.

Method: Cross-sectional analytic study with one group post-test only design was done in 25 dentists in the Dental Hospital Sultan Agung Semarang. The instrument for this research was used a questionnaire and a check list. Questionnaire was used to determine the level of knowledge, while the check list to determine the actions of the respondents. Data were analyzed with Pearson Correlation Test.

Result: The questionnaire and the check list that was used is valid and reliable. The results showed $95.8 \%$ of respondents have a good knowledge, $4.2 \%$ are good enough knowledgeand $0 \%$ is lackingknowledge. All respondents have a good action in the prevention of infectious diseases. Pearson correlation test results showed $p=0.041$, which means that there is a relationship between the level of knowledge of the dentists with the precautions against infectious diseases.

Conclusion: It can be concluded that there is a relationship between the level of knowledge of the dentists with the precautions of infectious diseases, where the strength of the correlation is moderate.
\end{abstract}

\section{PENDAHULUAN}

Petugas kesehatan gigi memiliki 10 kali lebih besar resiko menjadi pembawa hepapatitis $B$ kronis dibanding masyarakat biasa. Penelitian di Singapura menunjukkan tingginya kadar $\mathrm{HBsAg}$ dan $\mathrm{HBc}$ pada dokter gigi lebih tinggi lima kali lipat dibanding praktisi gigi lainnnya, diduga ini disebabkan oleh paparan air liur ${ }^{1}$.Di Amerika Serikat dilaporkan 2 orang penderita HIV tertular HIV dipraktek dokter gigi serta diperoleh bukti bahwa mereka tertular ditempat praktek dokter gigi yang tidak melakukan tindakan pencegahan secara ideal. Apabila di negara maju masih terdapat hal semacam itu, maka dapat diasumsikan bahwa di negara berkembang seperti Indonesia tindakan pencegahan masih belum memadai ${ }^{2}$.

Dokter gigi berkontak langsung dengan saliva atau darah pasien sehingga rentan terhadap resiko terkena penyebaran penyakit menular ${ }^{3}$.Contoh penyakit menular yang perlu diwaspadai oleh dokter gigi adalah Tuberkulosis, Acquired Immuno Deficiency Syndrom (AIDS), dan hepatitis B. Ditinjau dari masih banyaknya jumlah pengidap penyakit menular di Indonesia, maka seorang praktisi kesehatan seperti dokter gigi seharusnya sudah mempersiapkan prosedur keselamatan kerja seperti alat pelindung diri agar tidak

*Program Pendidikean Dokter Gigi Fakultas Kedokteran Gigi Universitas Islam Sultan Agung, **Departemen Kesehatan Gigi Masyarakat Fakultas Kedokteran Gigi Universitas Islam Sultan Agung

Korespondensi: annisa.meirani@ymail.com 
tertular penyakit menular apalagi saat ini kesadaran masyarakat terhadap pentingnya memeriksakan gigi ke dokter gigi sudah mulai tumbuh dibuktikan dengan data bahwa kunjungan masyarakat untuk mencabut gigi mengalami peningkatan pada tahun 2012 dibanding $2011^{4}$. Seorang dokter gigi sudah seharusnya melakukan prosedur keselamatan kerja seperti persiapan perlindungan diri (menggunakan alat pelindung diri), anamnesis, dan sterilisasi alat-alat ${ }^{5}$.

Setiap dokter gigi harus mampu memahami prinsip sterilisasi, desinfeksi, dan asepsis. Semua pengetahuan mengenai penyakit menular dan prinsip-prinsip tersebut telah disampaikan dalam pendidikan sarjana kedokteran gigi, sehingga kita perlu melihat apakah teori yang telah disampaikan dipahami dan dilaksanakan dengan baik oleh para dokter gigi yang telah menjalankan prakteknya. Sesuai dengan hadist Rasulullah SAW bahwa Allah mencintai kebersihan, sehingga kita sebagai umatnya wajib menjalankan apa yang Allah kehendaki.

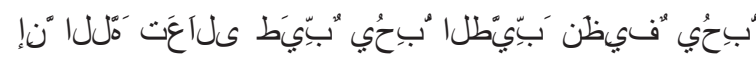

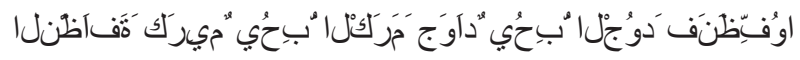

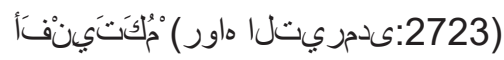

Sesungguhnya Allah swt. itu baik, Dia menyukai kebaikan. Allah itu bersih, Dia menyukai kebersihan. Allah itu mulia, Dia menyukai kemuliaan. Allah itu dermawan ia menyukai kedermawanan maka bersihkanlah olehmu tempat-tempatmu (H.R. at -Tirmizi: 2723).

Rumah Sakit Gigi dan Mulut Pendidikan adalah Rumah Sakit Gigi dan Mulut yang menyelenggarakan pelayanan kesehatan gigi dan mulut, yang juga digunakan sebagai sarana proses pembelajaran, pendidikan dan penelitian bagi profesi tenaga kesehatan kedokteran gigi dan tenaga kesehatan lainnya, dan terikat melalui kerjasama dengan fakultas kedokteran gigi ${ }^{6}$. Penelitian mengenai pengetahuan dan tindakan dokter gigi terhadap pencegahan penyakit menular sehingga peneliti merasa tertarik untuk meneliti hal tersebut di Rumah Sakit Gigi dan Mulut Pendidikan Sultan Agung belum pernah dilakukan.

\section{METODE PENELITIAN}

Jenis penelitian ini adalah cross sectional analitikdengan rancangan one group post test only design. Penelitian dilakukan pada total populasi yaitu 25 orang dokter gigi yang bekerja di Rumah Sakit Gigi dan Mulut Sultan Agung Semarang.

Pengetahuan dokter gigi muda dalam penelitian ini diperoleh dari kuesioner yang terdiri dari 30 pertanyaan dengan skor 1 (salah) dan 2 (benar) yang kemudian dibedakan atas: kurang (skor 30-40), cukup baik (skor 41-50) dan baik (51-60). Tindakan pencegahan penyakit menular oleh dokter gigi diukur menggunakan kuesioner berisi 15 pertanyaan dengan rentang skor jawaban 1-4 dan dikelompokkan sebagai: kurang (skor 1530 ), cukup baik (skor 31-45), dan baik (skor 46-60).

Uji korelasi pearson digunakan untuk menganalisis hubungan antara tingkat pengetahuan dengan tindakan pencegahan penyakit menular pada tingkat kepercayaan $95 \% \alpha=0,05^{7}$.

\section{HASIL PENELITIAN}

Dokter gigi sebagai responden dalam penelitian ini paling banyak berusia 31-40 tahun $(41,67 \%)$, sedangkan yang berusia 41-50 tahun dan lebih dari 50 tahun masing- 
masing sebanyak 29,17\% (Tabel 1). Tingkat pendidikan responden sebagian besar adalah spesialis $(62,5 \%)$, sedangkan untuk magister $29,17 \%$, dan doktoral hanya $12,5 \%$ (Tabel 2).

Tingkat pengetahuan responden berkisar antara skor 48-59 dengan nilai rata-rata $55,46 \pm 2,90$, sedangkan kisaran skor untuk variabel tindakan 47-60 dengan nilai rata-rata $55,67 \pm 3,59$ (Tabel 3).

Skor tingkat pengetahuan dan tindakan dokter gigi dalam pencegahan penyakit menular ditunjukkan pada tabel 4 dan 5 .

Tabel 1. Distribusi Frekuensi Usia Responden

\begin{tabular}{lcc}
\hline Kategori Usia(Tahun) & n & Prosentase \\
\hline $31-40$ & 10 & $41.67 \%$ \\
$41-50$ & 7 & $29.17 \%$ \\
$50<$ & 7 & $29.17 \%$ \\
\hline
\end{tabular}

Sebagian besar dokter gigi $(95,8 \%)$ memiliki pengetahuan yang baiktentang pencegahan penyakit menular, dan semua dokter gigi (100\%) juga memiliki tindakan yang baik dalam pencegahan penyakit menular.

Hasil uji korelasi Pearson antara tingkat pengetahuan dan tindakan didapatkan $r$ sebesar 0,410 dengan nilai $p=0,041$ karena $p<0.05$ maka disimpulkan bahwa terdapat hubungan antara tingkat pengetahuan dokter gigi dengan tindakan pencegahan penyakit menular. Kekuatan korelasi antar variabel Tabel 2. Distribusi Frekuensi Pendidikan Responden

\begin{tabular}{lcc}
\hline Kategori Pendidikan & n & Prosentase \\
\hline Program Spesialis & 15 & $62.5 \%$ \\
Program Magister (S2) & 7 & $29.17 \%$ \\
Program Doktoral (S3) & 3 & $12.5 \%$ \\
\hline
\end{tabular}

Tabel 3. Deskripsi statistik Tingkat Pengetahuan dan Tindakan

\begin{tabular}{lccccc}
\hline & N & Minimum & Maximum & Mean & Std. Deviation \\
\hline Pengetahuan & 24 & 48 & 59 & 55.46 & 2.904 \\
Tindakan & 24 & 47 & 60 & 55.67 & 3.595 \\
Valid N (listwise) & 24 & & & & \\
\hline
\end{tabular}

Tabel 4.Distribusi Frekuensi Tingkat Pengetahuan

Tabel 5. Distribusi Frekuensi Tingkat Tindakan

\begin{tabular}{|c|c|c|c|c|c|}
\hline Variabel & $\mathbf{n}$ & Prosentase & Variabel & $\mathbf{n}$ & Prosentase \\
\hline Tingkat Pengeta & & & \multicolumn{3}{|c|}{ Tingkat Tindakan } \\
\hline Kurang & 0 & 0 & Kurang & 0 & 0 \\
\hline Cukup baik & 1 & 4.2 & Cukup baik & 0 & 0 \\
\hline Baik & 23 & 95.8 & Baik & 24 & 100 \\
\hline
\end{tabular}

Tabel 6.Hasil Uji Korelasi Pearson

\begin{tabular}{ccc}
\hline & Pengetahuan & Tindakan \\
\hline PengetahuanKoefisien Korelasi & 1,000 &, $410^{*}$ \\
Sig. (2-tailed) & &, 047 \\
N & 24 & 24 \\
\hline Tindakan Koefisien Korelasi &, $410^{*}$ & 1,000 \\
Sig. (2-tailed) &, 047 & \\
N & 24 & 24 \\
\hline
\end{tabular}


bernilai positif dan termasuk kategori sedang.

\section{DISKUSI}

Nilai rata-rata responden pada kelompok pertanyaan pengetahuan adalah 55.46 hal ini menunjukkan sebagian besar responden memiliki tingkat pengetahuan yang baik. Hal ini karena tinggi rendahnya tingkat pendidikan seseorang mempengaruhi pengetahuan seseorang ${ }^{7}$. Semakin tinggi tingkat pendidikan maka pengetahuan akan semakin baik. Pengetahuan merupakan faktor penting dan berpengaruh terhadap seseorang atau kelompok untuk bertindak. Pengetahuan merupakan hasil dari tahu dan ini terjadi setelah orang melakukan penginderaan terhadap suatu objek tertentu ${ }^{8}$.

Nilai rata-rata kelompok pertanyaan tindakan pada responden adalah 55,67, juga termasuk dalam kategori baik. Tindakan yang baik dalam pencegahan penyakit menular ini didasari oleh pengetahuan yang baik. Pengetahuan merupakan suatu domain dari perilaku, domain lainnya yaitu sikap dan tindakan. Sebagian besar pengetahuan manusia diperoleh melalui pengalaman dan penginderaannya yang terutama adalah dari mata dan telinga. Pengetahuan dapat dipengaruhi oleh usia, informasi, pengalaman, dan pendidikan ${ }^{9}$.

Pengetahuan sangat penting dalam mendasari terbentuknya tindakan karena suatu perilaku dibentuk dari pengetahuan sehingga pengetahuan baru akan menimbulkan tanggapan batin dalam bentuk sikap dan akan timbul tanggapan lebih jauh berupa tindakan ${ }^{10}$. Pengetahuan yang baik tentang pencegahan penyakit menular yang dimiliki oleh dokter gigi dapat menentukan tindakan yang tepat dalamupaya pencegahan penyakit menular.
Hubungan antara pengetahuan dengan tindakan pencegahan penyakit menular yang dilakukan oleh dokter gigi termasuk dalam kategori sedang, artinya ada faktor lain yang terkait dengan tindakan tersebut. Berdasarkan Ariyani (2008) ${ }^{11}$, terkadang perlu diberikan perangsang (insentive) agar seseorang bersedia melakukan seperti yang diharapkan, perangsang dapat berupa perangsang negatif yang merupakan imbalan tidak menyenangkan berupa hukuman bagi seseorang ataupun yang berbuat tidak seperti yang diharapkan, antara lain seperti denda, teguran dan pemberhentian. Maupun perangsang positif yang merupakan imbalan menyenangkan yang disediakan untuk seseorang yang berprestasi seperti hadiah, penghargaan dan promosi ${ }^{11}$.

Penelitian ini memiliki keterbatasan yakni menggunakan metode penelitian cross sectional yang merupakan teknik penelitian yang lemah sebab tidak dapat mengendalikan faktor-faktor lain yang mempengaruhi hubungan antar variabel. Dikarenakan keterbatasan waktu peneliti maka kuesioner mengenai pengetahuan dan tindakan hanya diuji validitas dan realibilitas sekali saja. Disamping itu pengamatan hanya dilakukan sekali karena keterbatasan waktu peneliti. Hambatan lainnya adalah ada responden yang menolak dan tidak mau memberikan pendapatnya dalam pengisian kuesioner dikarenakan kesibukan responden.

\section{KESIMPULAN}

Kesimpulan yang diperoleh dari penelitian ini antara lain yaitu: 1) Terdapat hubungan yang signifikan antara pengetahuan terhadap tindakan Dokter Gigi dalam upaya pencegahan penyakit menular, dengan kategori kekuatan hubungan yang sedang, 2) tingkat pengetahuan 
Dokter Gigi dalam upaya pencegahan penyakit

menular tergolong baik (95,8\%), dan 3) tingkat

tindakan Dokter Gigi dalam upaya pencegahan

penyakit menular tergolong baik (100\%).

\section{DAFTAR PUSTAKA}

1. Kuswadji S. 1994. Penyakit Akibat Kerja pada Dokter, Dokter Gigi, Perawat dan Tenaga Kesehatan lainnya. JDKI, 2; 6; 37-40.

2. Sondang, P. AIDS dan pencegahan penularannya pada praktek dokter gigi. USU Institutional Repository. http://repository.usu.ac.id/handle/123456789/1147 (2004). Diunduh 21 April 2015.

3. Pedersen, G. 1996. Buku Ajar Praktis Bedah Mulut (Oral Surgery). Jakarta : EGC.

4. Dinas Kesehatan Jawa Tengah. 2012. Profil Kesehatan Provinsi Jawa Tengah.

5. Depkes R.I. 2003. Pedoman Penyelenggaraan Rumah Sakit Gigi dan Mulut. Jakarta :Departemen Kesehatan Republik Indonesia

6. Kemenkes RI. 2013. Pedoman Pencegahan dan Pengendalian Infeksi Kasus Konfirmasi atau Probabel Infeksi Virus.

7. Dahlan, Sopiyudin. 2011. Statistika Untuk Kedokteran dan Kesehatan. Jakarta: Salemba Medika, H: 169174.

8. Sindhunata. 2000. Menggagas Paradigma Baru Pendidikan. Yogyakarta : Kanisius.

9. Notoatmodjo, S. 2003. Pendidikan dan Perilaku Kesehatan. Jakarta : PT Rineka Cipta.

10. Budiharto. 2008. Metodologi Penelitian Kesehatan dengan Contoh Bidang IImu Kedokteran Gigi. Jakarta : Penerbit Buku Kedokteran EGC.

11. Ariyani. Analisis Pengetahuan dan Motivasi Perawat yang Mempengaruhi Sikap Mendukung Program Patient Savety. Thesis. Semarang: Fakultas IImu Kesehatan Masyarakat Universitas Diponegoro (2008). 